\title{
ARMAMENTS USED IN THE UKRAINIAN CONFLICT 2014-2015
}

\author{
Artur PLOKŠTO \\ Maj. Andriej DEMEŠKO \\ Ministry of National Defence, Republic of Lithuania \\ aploksto@yahoo.com
}

\begin{abstract}
The development of events in Ukraine at the end of 2014 led to the outbreak of armed fighting in Donbas, where virtually all kinds of land forces' arms were used, not only of Soviet or Russian production but also the latest ones and armaments that had been previously withdrawn from operation. The purpose of this paper is to investigate the armaments used during the fighting in the Donbas region, innovations in weaponry and tactics in the period from April 2014 to the middle of February 2015. The study is based on the qualitative analysis of primary source materials from photographs and video clips available in free circulation as well as information shared in online forums (particularly Russian ones) and unstructured interviews with the participants of those events. The findings of the study pertain to the kinds of Soviet and Russian land forces' armaments in a real combat situation as well as the tactics involved in using them.
\end{abstract}

Key words: Ukraine, conflict, armament

\section{Introduction}

The development of events in Ukraine at the end of 2014 led to the outbreak of armed fighting in Donbas. During the first period of fighting, the fundamental problem was logistics, after the start of mobilisation - provisioning of equipment and weapons were the biggest challenges. The core of operations was conducted 
mainly with tanks fitted with reactive armour, replacing the armour after loss if necessary. The basic destructive force was artillery, including rockets. Substantial usage of heavy machine guns and automatic grenade launchers was widely employed which penetrated vests and other obstacles, including the use of antimateriel rifles. There was a rapid increase and demand for flash suppressors, night vision and thermal vision devices. Vast importance was given to UAVs as well as to the significant role of electronic warfare, and the main challenges associated with combatting UAVs. Light armoured vehicles became the main source of human losses. It was essential to restore the combat readiness of equipment as soon as possible. Moreover, the conflict created the possibility to subsequently check the essential characteristics of these arms in real battlefield conditions and acquire information on innovations in tactics, how they are applied, and the modernisation measures taken.

This article attempts to examine armaments, the new kinds of equipment and tactical steps used in Donbas, limited, however, only to land forces' armaments. The time period under analysis covers April 2014 (beginning of fighting) to the middle of February 2015 (liquidation of the Debaltseve "kettle"). The data was obtained from primary source materials from photographs and video clips available in free circulation as well as information shared in online forums (particularly Russian ones) and interviews with the participants of those events. The material was collected by monitoring daily media and its development over time; particular facts were later checked in online forums and confirmed in unstructured interviews with the participants. Internet sources were also checked in the context of additions to the earlier information.

The article consists of three parts. The first part deals with the development of war operations and a review of the confronting forces (highlighting basic information), the second one features an analysis of armaments used in the conflict (according to their types) and the third part offers conclusions. 


\section{Review of war operations and confronting forces}

\section{Development of events}

On 7 April 2014, separatists attacked Ukraine's Security Service building in Donetsk, took control of it and proclaimed a Donetsk People's Republic; similar events took place in Luhansk. This date may mark the beginning of the armed conflict. On 9 April, Ukraine's Interior Minister Arsen Avakov stated: "the situation in the region of ATO (antiterrorist operation) may change within 48 hours", having in mind the swift pacification of the rebellion. He was not right...

In spring 2014, Ukraine had, maybe not the most modern, but yet an Armed Force comprising all services and all kinds of armaments from the former Soviet Union (apart from nuclear weapons because Ukraine had given them up at the OSCE summit of 5 December 1994 when it signed the Budapest Memorandum on Security Assurances). At the beginning of the rebellion in the south - east region, the Ukrainian General Staff managed to gather about 10 - 15 thousand soldiers and around 250 armoured vehicles; apart from them, it also had the artillery and air force at its disposal. Separatists' forces did not amount to more than $2-3$ thousand fighters ${ }^{1}$ and they were spread over the Donetsk and Luhansk region. Determining which forces were supporting separatists at the beginning of the conflict is virtually impossible as this information is highly biased from both conflicting sides. At the beginning of the operation, the Ukrainian side had a decisive quantitative and technical advantage. However, they were not able to make use of it due to the fact that their military structures were not prepared to carry out real conflict tasks and had inefficient control of the operation. Later, the separatists received military and logistics support from the Russian Federation's side and that equalled the balance of power.

The analysis of information appearing in open sources allows us to divide the development of separatist forces into a few stages:

1 A. Sharkovsky, Война на юго-востоке Украины меняется качественно, Nezavisimoe Voennoe Obozrenie, 22.05.2015, http://nvo.ng.ru/realty/2015-05-22/1_ukraina.html [accessed: 8.08.2015]. 
- February - March 2014 - small groups of activists armed with simple, often improvised devices (clubs, Molotov's cocktails, civilian fire-arms);

- April - June 2014 - separatists appeared to have organised structures, assault rifles, some armoured vehicles. The low-intensity period began, i.e. ambushes, attacks on particular buildings ${ }^{2}$;

- June - September 2014 - the beginning of intensive fighting with the use of heavy armour i.e. tanks, self-propelled guns and rocket artillery;

- From September 2014 till the end of intensive fighting - transformation of separatist forces into a regular army.

\section{Separatist forces}

According to the Ukrainian side's information ${ }^{3}$, separatist forces in 2014 could be divided into two categories: combat and reserve units. The reserve units, in principle, corresponded to combat units in their structure and functions.

Combat units operating in one region usually consisted of $2-3$ mobile groups. The internal structure, formally copying the classical military structure, was characterised by its great flexibility and was most often adjusted ad hoc to a performed mission. It usually contained:

- 2-3 combat groups of changeable composition of manpower (up to 120 fighters). Later on, each major unit had a curator (guardian) - which the Ukrainian side identifies as representatives of the Main Intelligence Agency of the General Staff of the Armed Forces of the Russian Federation;

- a supply group responsible for all logistics;

- a support element, usually local civilians. Indeed, they were used as reserves, guides, scouts etc.;

- a group of specialists - snipers, operators of mortars, guns and grenade launchers, sappers, signallers etc.;

2 Від вибуху на, Аонеччині постраждало двоє військових, один з них помер, Ukrainska Pravda, 28.04.2014, http://www.pravda.com.ua/news/2014/04/28/7023883/ [accessed: 8.08.2015].

3 Col. Dmytro Kobec's presentation at the conference in Tartu on 27 January 2015. 
- in the later periods, when success of the action was expected - a journalist with a TV camera.

In the period of spring - autumn 2014, the basic fights of separatists included:

- Providing control of the key terrain. From the military point of view, these are towns where military bases or police centres were seized; later, strengthened outposts were built, and if needed, fortification works were conducted ${ }^{4}$.

- Setting up ambushes. The beginning dates back to 13 May 2014 when a column of Ukrainian soldiers were attacked and destroyed ${ }^{5}$ near Kramatorsk. Similar ambushes were laid not only in the Donetsk and Luhansk areas but also outside them (e.g. in the region of Kharkiv $\left.{ }^{6}\right)$.

- Attacks on separate targets. Small objects, facilities or units were usually attacked. The aim of those attacks was to take over property or its destruction, and sometimes seize control of a territory. The success of the attack depended on the ability to gain a local tactical advantage and the use of surprise; for instance, a separatist attack commanded by Igor Bezler ("Bes") on the 51st Mechanised Brigade's fortified post on 22 May 2014 .

Later, the attacks were launched using heavy armour, tanks and artillery systems including the. destruction of a fortified post in Sloviansk on 28 May 2014.

- Sabotage and subversive operations ${ }^{9}$. According to the Ukrainian side, separatists' subversion operations were carried out by fighters trained in Russia taking advantage of facilities of 22nd Spetsnaz Brigade's base. The number of fighters trained there is estimated at approximately 2200 , and usually they

4 S. Gerasimov, Видео Эксклюзив МОТОРОАА проверил боевые позиции в Семеновке, 05.06.2014, https://www.youtube.com/watch?v=LalrD23V61s [accessed: 15.08.2015].

5 Y. Domasheva, E. Azeev, L. Sidorenko, Под Краматорском погибли шесть украинских военных, Komsomolskaya Pravda v Ukraine, 13.05.2014, http://kp.ua/politics/452433-podkramatorskom-pohybly-shest-ukraynskykh-voennykh [accessed: 25.08.2015].

6 Колонна украинских военных попала в засаду в Харьковской области, Fосия, 10.06.2014, http://focus.ua/country/308099/ [accessed: 25.08. 2015].

7 In the attack, there were about 13 Ukrainian soldiers killed, 20 wounded, and 3 APCs were destroyed. Among the separatists the death toll was 9 and 17 were wounded. Террористы расстреляли украинских солдат под Волновахой, Sait Mariupola 0629. cm.ua, 22.05.2014, http://www.0629.com.ua/article/539570, https://www.youtube.com/ watch?v=9yEhQ21BrCA [accessed: 30.08.2015].

8 Y. Kasyanov, Как был уничтожен 1-й блокпост, Cenzor.net, 28.06.2014, http://censor. net.ua/resonance/291942/kak_byl_unichtojen_1yi_blokpost [accessed: 25.08. 2015].

9 This information was provided by Col. Dmytro Kobec at the conference "Ukrainian Crisis" in Tartu on 27 January 2015. 
were citizens of both Ukraine and Russia, often with a criminal record. Similar structures quickly began to form around charismatic leaders.

At the end of 2015, the separatist forces were transformed into a regular army thanks to the help of specialists from the Russian Federation. This process did not proceed peacefully as several renowned commanders of more independent armed formations died in unclear circumstances ${ }^{10}$. During the fighting, torture was inflicted on captives, abductions took place, and trafficking of important prisoners of war conducted by local war lords flourished ${ }^{11}$. The Don Cossacks, famous for their internal democracy, verged on anarchy (and their valour), were at the forefront of those actions.

Today, separatist armed forces consist of two corps (32-35 thousand soldiers). The command amounting to 1200 officers is completely controlled by Moscow and both "people's republics' titular leaders" do not have any practical influence on them.

\section{Ukrainian armed forces}

At the initial stage of the conflict, regular Ukrainian armed forces were not able to carry out effective operations in asymmetric conflict conditions. The following reasons contributed to it:

- many years of armed forces' underfunding and consequently weak logistics support,

- disorganisation of state management structures and lack of coordination between particular institutions,

10 F. Mahmudov, Commander of "Ghost" brigade (LPR Army) Aleksey Mozgovoy was assassinated, APA, 23.05.2015, http://en.apa.az/world-news/cis-countries-news/ commander-of-ghost-brigade-lpr-army-aleksey-mozgovoy-was-assassinated.html [accessed: 30.08.2015]; M. Moshkin, Атамана Батю взорвали в автомобиле после свадьбы, Delovaya Gazeta Vzglyad, 12.12.2015, http://www.vz.ru/incidents/2015/12/12/783478. html [accessed: 30.12.2015]; G. Naberejnov, В Ауганске убит обвиняемый в пытках командир ополчениев «Бэтмен», RBK, 2.01.2015, http://www.rbc.ru/politics/02/01/2015/ 54a6ad809a794737b58c4ea3 [accessed: 30.07.2015].

11 Игорь (Бес) Безлер: начнем наступление, когда противник выдохнется, RIA Novosti, 16.07.2014, http://ria.ru/interview/20140716/1016094469.html\#ixzz4C79pAgHl [accessed: 30.08. 2015]. 
- failure to prepare Ukraine's armed forces' structures for real conflict,

- lack of new authorities' trust in the units of the Ministry of Internal Affairs and Ministry of Defence (Crimean events during which only $25 \%$ to $38 \%$, depending on the source, of Ukrainian soldiers opted for Ukraine),

- lack of reserves,

- information and logistics support for separatists from the Russian Federation.

Regular armed forces of the Ukrainian state were very soon supported by voluntary forces of various origins.

\section{Regular forces}

The basic tactical units of Ukrainian armed forces include battalion and company tactical groups established in tank, mechanised and airmobile brigades. The company tactical groups were formed on the basis of an infantry company, adding a tank platoon, reconnaissance sub-unit, artillery battery (towed howitzers D30), snipers' section and logistic and maintenance subunits. Experience gained in spring 2014 changed the structure of company tactical groups, whose composition included a company of motorised infantry, tank platoon, mortar/guns artillery platoon and a rocker artillery platoon. Currently, such a tactical group consists of $250-450$ soldiers, 20 - 25 APCs/IFVs, 6 - 12 towed or self-propelled howitzers and up to 6 rocket artillery launchers. Tactical groups were created because of staff shortages. The limited call-up for mobilisation did not manage to fill them - for instance, on 12 July 2014, brigades were manned at 30-50\% of the peacetime structure.

Another problem for the Ukrainian government forces was the lack of logistics and maintenance capabilities, which they attempted to solve by creating maintenance groups formed of employees of the Kharkiv tank manufacturing plant and other maintenance plants. 
National Guard of Ukraine Units, separate gendarmerie battalions of territorial defence

The new Ukrainian Interior Minister Arsen Avakov started creating voluntary paramilitary formations. At the beginning of 2014, the troops of the Ministry of Internal Affairs were renamed the National Guard. However, there was a problem with their loyalty towards the new Ukrainian authorities ${ }^{12}$. Therefore, voluntary formations established during fights on Kiev's Maidan were incorporated into the composition of the National Guard - in this way the $1^{\text {st }}$ Battalion of National Guard (later renamed Gen. Kultchytski battalion ${ }^{13}$ ) was set up. Then, the Donbas battalion was established. Ordinary National Guard's battalions had a motorised battalion structure, equipped with APCs (BTR-3 - BTR-4), whereas "named" ones had a special forces' structure.

Apart from the National Guard, new units emerged, in many cases in a chaotic way and without legal empowerment (by August 2014). It is not easy to estimate their number and composition since volunteers often formed the units themselves, choose their commanders and moved to the area of operation. They usually comprised of 100-200 fighters, and the Ukrainian Ministry of Internal Affairs equipped them with light weapons. Some of them became famous, i.e. two battalions of the political party "Pravyi Sektor" and the battalion "Azov" which were later transformed into a regiment.

Territorial defence battalions were set up on the basis of local war stations, and were supposed to consist of three infantry companies without heavy or armoured equipment using civilian means of transport to relocate. The first strike battalions (24th "Aidar"; 11th "Kievan Rus", 40th „Krivbas") were equipped as a result of oligarchs' and private sponsors' assistance. Although they suffered heavy losses in the 2014 campaign, their manpower levels were $60-80 \%$ filled. Battalions of the second and third strike looked different, the manpower reached only $20-30 \%$, and they experienced great shortages of equipment, especially communications.

12 Don't forget that the events in Maidan just finished and internal troop formations were behind a different side of the barricade...

13 Lt.Gen. Sergey Kultchystki, the chief of National Guard Department of combat and special training, died in a helicopter crash after it was shot down by separatists in Donbas on 29 May 2014. 
One thing which was not missing was motivation. In this respect, these units significantly differed from regular units and it must be acknowledged that both formations did not like each other.

\section{Armaments and military technology used in the conflict}

The analysis of photo and video material clearly shows that both sides used armament systems produced in the USSR. However, in the course of operations, there appeared ad hoc modified, even home-made methods and pieces. The direction of the performed changes shows the new requirements of the battlefield, particularly concerning all types of flash suppressors, sights, night and thermo-vision, communications and electronic warfare elements as well as using Unmanned Aerial Vehicles (UAVs).

\section{Handguns}

Handguns from the armament category moved to the power attribute category. Igor Girkin („Strielkov”) was the commander-in-chief of pro-Russian separatists at the beginning of 2014, and always boasted of the legendary Mauser 96C in pictures, Alexander Zakharchenko, a leader of the self-proclaimed Donetsk People's Republic, appears in public with an APS pistol. Ukrainian leaders are equipped with Glocks. There is no real need to carry pistols, as behind the officials' backs were bodyguards not only with handguns but assault rifles and other armaments as well.

Submachine guns

Submachine guns became a thing of the past after the end of World War 2 and the introduction of the Kalashnikov gun into the armed forces' equipment. However, a large number of them are still stored. At the beginning of the conflict, it was 
possible to see PPSh-41 and PPS-43 in separatists' hands, but soon it appeared that the range of shooting was highly insufficient. Despite this, separatists attempted to launch a small series production of submachine guns for diversion groups, but they did not start it due to the arms supply from the Russian Federation.

\section{Assault rifles}

Both sides have been using the immortal Kalashnikovs in various modifications. New trends included great interest in flash suppressors; in many cases, they appeared to be "homemade" constructions with different consequences. The main goal of these modifications was to avoid exposing the shooter, especially at night.

There also appeared a large number of holographic sights assembled laterally (only those fit to a standard Kalashnikov), from many producers, not necessarily Russian ones. Equipping soldiers with thermal vision imaging is still an unsolved problem although there have been attempts to fill this gap with equipment from the civilian market.

A photo of a Kalashnikov very nicely converted into a bullpup also surfaced. However, does such an upgrade make sense?

Similarly, the experience of the conflict shows that the characteristics of the ammunition used had a distinct impact on the effectiveness of fire, when hostile forces extensively use modern individual protection equipment.

\section{Heavy anti-materiel rifles}

After active operations started in spring 2014, it very soon became apparent that the Ukrainian forces had an advantage on the battlefield due to their employment of light armoured warfare tactics, against which separatists' pistols and rifles with an intermediate cartridge were useless. The separatist solution came unexpectedly, namely in the nooks of stores where they found $14.5 \times 114 \mathrm{~mm}$ calibre anti-tank rifles. They were first used in combat during the siege of Sloviansk. Initially they were PTRSs 
with five-round magazines, later single-shot PTRDs (whose lock was copied from the Polish anti-tank rifle UR...). There were no problems with finding ammunition because they were supplied with popular cartridges used in the KPVT heavy machine guns, and standard equipment of older APC BTR 60/70/80 variants.

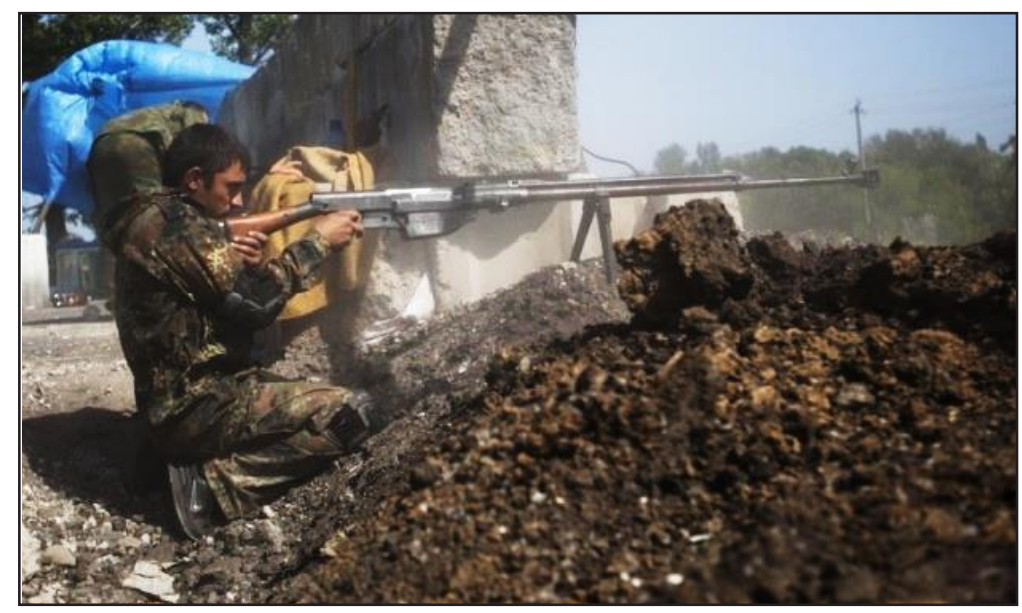

AP Photo/Alexander Zemlianichenko; http://www.whq-forum.de/invisionboard/index.php?sho wtopic $=29782 \& \mathrm{st}=2793$.

Pro-Russian militant battle fires the anti-tank rifle PTRS-41 against Ukrainian government troops at a checkpoint blocking the major highway which links Kharkiv, outside Slovyansk, eastern Ukraine. 2014-05-18

PTRDs were used intensively during the battles at Doneck airport as the cartridge's energy allowed it to easily penetrate walls built according to modern technologies. The use of large calibre rifles has also been proven against the use of light armoured vehicles (especially in urban areas) and sniper terror, under conditions that are relatively stable at the front line.

Later in the conflict zone, separatists also used Russian large calibre ASWK, (12.7x108 $\mathrm{mm}$ ) which was introduced into Russian armaments in 2013. It is a bolt action weapon, bullpup-configured. The Ukrainian side had at its disposal very few Barrett M82A1semiautomatic large calibre rifles, which were bought by Bulgarian middlemen ${ }^{14}$.

14 Игорь (Бес) Безлер: начнем наступление, когда противник выљохнется, RIA Novosti, 16.07.2014, http://ria.ru/interview/20140716/1016094469.html\#ixzz4C79pAgHl [accessed: 30.08. 2015]. 


\section{Machine guns}

In combat operations in the east of Ukraine, a wide range of older manufactured and modern machine guns could be seen, from the period of the Russian tsar to modern times.

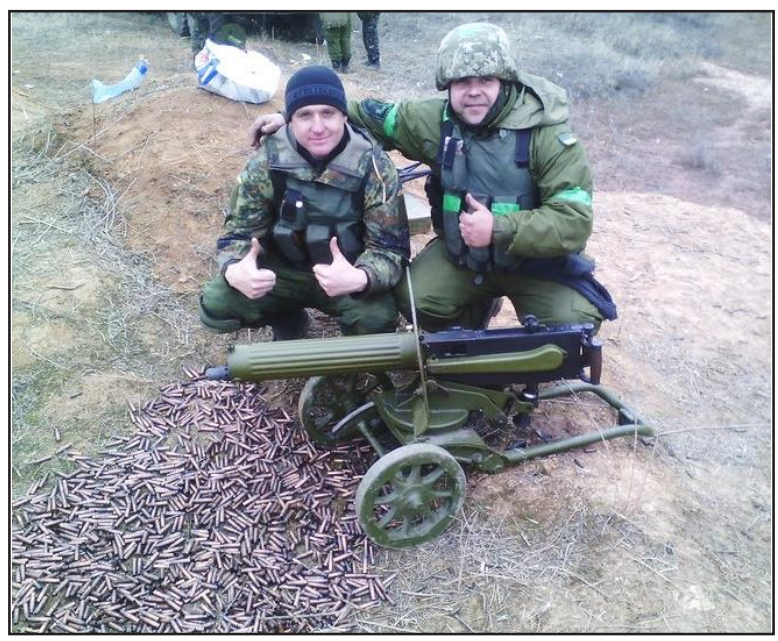

http://codename-it.livejournal.com/945063.html

Maxim machine gun, model 1910/30, after Ukrainian soldiers test firing, 2015-03-15

\begin{tabular}{|c|c|c|}
\hline Type & Ammunition & Remarks \\
\hline \multicolumn{3}{|c|}{ Ukrainian forces } \\
\hline \multicolumn{3}{|c|}{ Light machine guns } \\
\hline RPK & $7.62 \times 39 \mathrm{~mm}$ & \multirow{4}{*}{$\begin{array}{l}\text { Weapons stored as strategic reserves, after } 2014 \text { failure } \\
\text { and beginning of forming new brigades it was brought } \\
\text { back to service. }\end{array}$} \\
\hline RPK-74 & $5.45 \times 39 \mathrm{~mm}$ & \\
\hline DPM & $7.62 \times 54 \mathrm{mmR}$ & \\
\hline RPD & $7.62 \times 39 \mathrm{~mm}$ & \\
\hline \multicolumn{3}{|c|}{ General-purpose machine guns } \\
\hline PK & $7.62 \times 54 \mathrm{mmR}$ & \\
\hline PKM & $7.62 \times 54 \mathrm{mmR}$ & \\
\hline M53 & $7.62 \times 51 \mathrm{~mm}$ & $\begin{array}{l}\text { The model produced in former Yugoslavia, captured by } \\
\text { separatists in spring } 2014 \text {. }\end{array}$ \\
\hline \multicolumn{3}{|c|}{ Heavy machine guns } \\
\hline Maxim M1910 & $7.62 \times 54 \mathrm{mmR}$ & \multirow{3}{*}{$\begin{array}{l}\text { Weapons stored as strategic reserves, after } 2014 \text { failure } \\
\text { and beginning of forming new brigades it was brought } \\
\text { back to service }\end{array}$} \\
\hline SG-43 & $7.62 \times 54 \mathrm{mmR}$ & \\
\hline DShK & $12.7 \times 108 \mathrm{~mm}$. & \\
\hline NSV „Utios” & $12.7 \times 108 \mathrm{~mm}$. & \\
\hline KPV/KPVT & $14.5 \times 114 \mathrm{~mm}$. & Armament APC BTR 60/70/80 \\
\hline
\end{tabular}




\begin{tabular}{|l|l|l|}
\hline Type & Ammunition & Remarks \\
\hline Separatist forces/ Russian Federation \\
\hline Light machine gun \\
\hline RPK-74 & $5.45 \times 39 \mathrm{~mm}$. & \\
\hline General-purpose machine guns & \\
\hline PK & $7.62 \times 54 \mathrm{mmR}$ & \\
\hline PKM & $7.62 \times 54 \mathrm{mmR}$ & \\
\hline „Pecheneg” & $7.62 \times 54 \mathrm{mmR}$ & $\begin{array}{l}\text { Upgraded machine gun PKM, only in the Russian } \\
\text { Federation's stocks }\end{array}$ \\
\hline Heavy machine guns & & \\
\hline DShK & $12.7 \times 108 \mathrm{~mm}$. & From stores \\
\hline NSV „Utios” & $12.7 \times 108 \mathrm{~mm}$. & \\
\hline KPV/KPVT & $14.5 \times 114 \mathrm{~mm}$. & Mounted ad hoc on trucks and pick-ups. \\
\hline
\end{tabular}

a) Victor Muzhenko, Chief of General Staff of the Ukrainian Armed Forces, when asked during a meeting in November 2016 how antique Maxims perform in the battlefield answered "on the stationary posts of resistance they perform perfectly. Moreover, we have over 30000 of them in our stores...."

Table 1. Machine guns used in Ukraine in 2014-2015

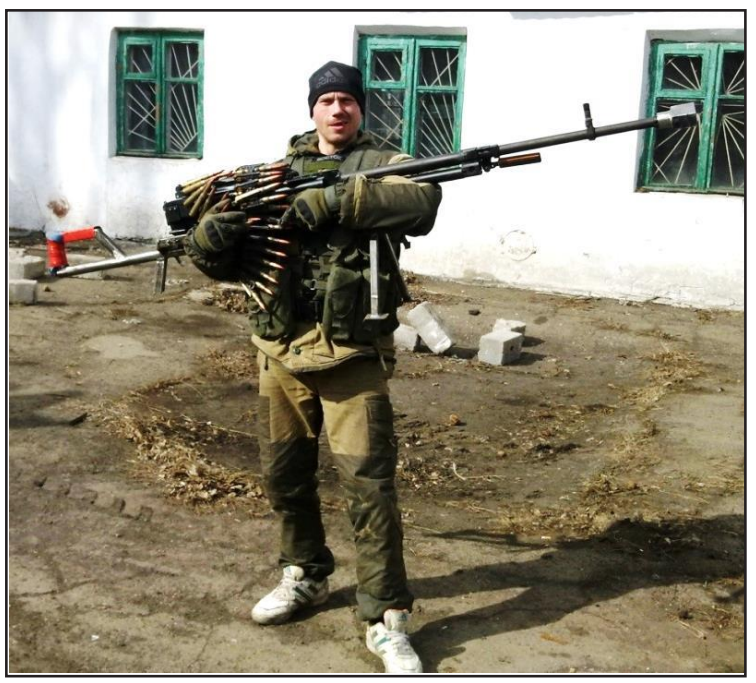

http://otvaga2004.mybb.ru/viewtopic.php?id=796\&p=27.

Homemade 12,7 mm Utios heavy machine gun modernisation. Separatist group "Somali“, 2015-03-15

During the conflict, both fighting sides upgraded machine guns mainly by producing devices to mount various sights and silencers and flash suppressors. There were attempts to mount muzzle brake and light bipods on the NSV "Utios" heavy machine gun, in order to increase its manoeuvrability. 
The Ukrainian side organised the machine gun tripods and bipods supply mainly in order to compensate for the losses. However, it was very strange on a global scale when Ukraine introduced the Maxim M1910 heavy machine gun, known now only from historical films, and which shows the real scale of equipment shortages they faced after the first period of fighting.

Favoured by both sides, various pods were made by craftsmen in order to set the heavy machine guns on improvised wheeled platforms, often home-made armoured.

Medium and heavy machine guns once again proved their effectiveness, and it can be noted that these types of machine guns were used from closed positions. It was not possible to find any information on the use of intermediate calibre ammunition.

\section{Grenade launchers}

Both Ukrainian and separatist sides used standard Soviet grenade launchers (cf. Table 2).

\begin{tabular}{|l|l|}
\hline Grenade launcher & Types of grenades \\
\hline RPG-7 & $\begin{array}{l}\text { PG-7, PG-7L, PG-7M, PG-7S, OG-7 HE-FRAG, } \\
\text { TBG-7 }\end{array}$ \\
\hline RPG-18; & PG-18 HEAT \\
RPG-22 & \\
RPG-26 & \\
\hline $\begin{array}{l}\text { RPO -A Shmel (rocket-propelled flamethrower } \\
\text { - A Bumblebee) }\end{array}$ & $\begin{array}{l}\text { Thermobaric } \\
\text { RShG-1 (rocket-propelled grenade launcher) }\end{array}$ \\
\hline SPG-9 & PG-9 HEAT; OG-9 FRAG-HE \\
\hline AGS-17 (30 mm, automatic) & WOG-17A; WOG-30 \\
\hline
\end{tabular}

Table 2. Overview of grenade launches used by both sides 
There were attempts to increase the RPG-7 grenade explosive power by mounting a $82 \mathrm{~mm}$ mortar mine to the grenade deactivating in this way its self-destruction function ${ }^{15}$.

The RPO-A confirmed its highly regarded capabilities as an exceptionally effective weapon in urban terrain. It was used, inter alia, to fire at buildings from which snipers operated.

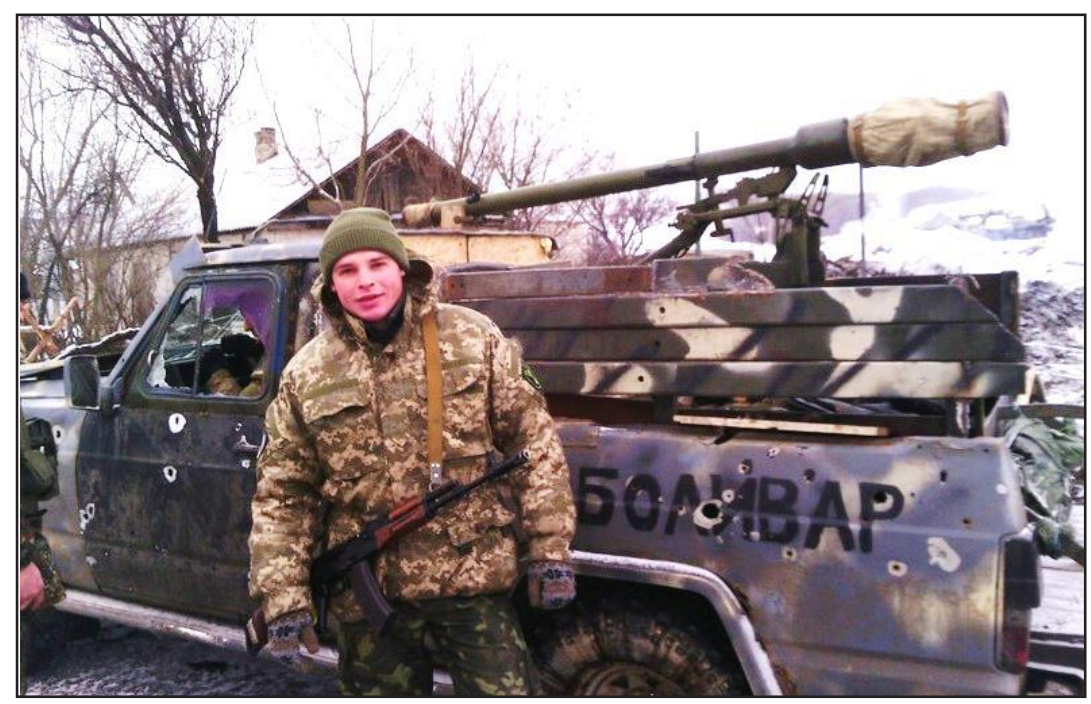

http://codename-it.livejournal.com/763223.html.

Ukrainian gun truck after battle. Fitted with 6G6 SPG-9 recoilless gun. Donetsk region

The SPG-9, a forgotten grenade launcher (or recoilless gun) was verbally reborn as it proved useful to conduct indirect fire and was successively used to perform this function.

The AGS-17, an automatic grenade launcher, proved to be very effective due to its relatively light weight. It was mounted on various platforms, inter alia, on vans without rear doors to carry out rapid fire attacks and quick retreats.

15 РПГ с зарядом мины Ноу хау от АУК Правый Сектор, https://www.youtube.com/ watch?v=gRpoZuxq7rw [accessed: May 2016]. 


\section{Use of UAVs in Ukraine}

The armed conflict in Ukraine resulted in very intensive use of UAVs which, since the autumn of 2014, have become a significant and essential element especially in the artillery guidance systems.

\section{General overview of constructions used}

Contrary to other contemporary conflicts, war operations in the east of Ukraine created such a need for UAVs that apart from series production constructions, there were widely used civilian models or amateur constructions completed ad hoc from available elements. Both sides used UAVs, whose characteristics comply with CLASS I requirements ${ }^{16}$.

UAVs used were constructed as aircraft (fixed wings) or helicopter (rotary wings, usually multi rotor choppers). The table below shows the conclusions of their use in Ukraine.

\begin{tabular}{|l|l|l|}
\hline Kinds & Strengths & Weaknesses \\
\hline Fixed wings & $\begin{array}{l}\text { - Longer flying range } \\
\text { - Longer flight time } \\
\text { - Lower price } \\
\text { - Simpler service }\end{array}$ & $\begin{array}{l}\text { - Operators must undergo special training } \\
\text { - Dependency on landscape features, } \\
\text { especially while landing }\end{array}$ \\
\hline $\begin{array}{l}\text { Rotary } \\
\text { wings }\end{array}$ & $\begin{array}{l}\text { Independence from landscape } \\
\text { features }\end{array}$ & $\begin{array}{l}\text { - Shorter flying range } \\
\text { - Dependency on ambient air temperature } \\
\text { Damage or failure of one rotor causes the } \\
\text { Dhole UAV to crash }\end{array}$ \\
\hline
\end{tabular}

Table 3. UAVs types

16 Joint Doctrine Note 3/10 Unmanned Aircraft Systems: Terminology, Definitions and Classifications has been archived and is not the authoritative reference, https://www.gov. uk/government/uploads/system/uploads/attachment_data/file/432646/20150427-DCDC_ JDN_3_10_Archived.pdf. 
Both the Ukrainians and the separatists used fixed wing UAVs for long patrol missions, whereas rotary wings were used for close reconnaissance operations. Fixed wing UAVs can be divided into classical ones and flying wing. The classical type demonstrated a longer range due to their larger wing surface and were more stable while flying. However, their transport and assembly, very often close to the battlefield, caused big problems (time consuming assembly and disassembly). Flying wings had worse flying parameters but were less demanding in service and, in principle, less damage occurred while landing.

Ukrainian experience shows that the UAV's operational flying range should provide reconnaissance information from an area of about 3 square kilometres, and in the event of artillery fire correction, not less than 15 minutes. The required range of a light UAV amounted to $25-35 \mathrm{~km}$, with a flying time between 60 and 90 minutes. If good weather conditions existed, on returning, a UAV should have $10 \%$ of its energy or fuel remaining. Mini UAVs operated at a $200-300 \mathrm{~m}$ altitude, the heavier ones at $300-1500 \mathrm{~m}$. The altitude of the flight depended mostly on the resolution of the reconnaissance equipment and weather conditions ${ }^{17}$. The exploitation of heavier UAVs, particularly combustion engine driven types, caused serious problems in some cases as, at low altitude, they were easy to detect and shoot down.

As far as surveillance heads are concerned, NATO countries usually use highly sophisticated and expensive multifunctional devices. However, Ukrainian experience shows that a simple commercial camera was sufficient in many cases. The optimal solution was the GoPro 4 camera, which allows $4 \mathrm{~K}$ resolution (3.840 px $\times 2.160$ px) to be achieved. The camera has the ability to enlarge up to $280 \%$ with no loss of image quality; consequently one could watch a strip of 700 metres from an altitude of 250 metres. Night surveillance was not widely applied due to the fact that piloting such a UAV is complicated, the equipment (thermographic camera and night vision) is expensive, and image identification is problematic.

The separatist side was quickly equipped with systems to jam communication with the UAVs. Therefore, the Ukrainian UAV's trajectory was in principle programmed in advance without the possibility to operate it in real time.

17 Cloudiness dominates in Donbas from October to April. The ceiling of clouds amounts to $300 \mathrm{~m}$. 


\section{Counter UAVs}

Attempts to combat UAVs in Ukraine evolved in two ways: by using small arms and rockets as well as applying electronic warfare. Air defence systems (usually 9K38 Igla) proved to be effective against combustion engine driven UAVs which left a clear visible thermal signature. A video showing a separatist UAV shooting down a UAV with a 9K37 Buk missile system reveals the basic problem with countering UAVs, i.e. inadequate cost of firing. In addition, the $23 \mathrm{~mm}$ anti-aircraft cannons were also used.

The conflict in Donbas demonstrated clearly that nowadays there are no crystallized effective ways to combat UAVs, which poses a great challenge to both science and industry as well.

The experience gained from this conflict shows that:

- The massive, continuous use of commercial UAVs makes it possible to significantly increase tactical intelligence and improve the quality of information received, which in turn can significantly increase the use of weapons (especially artillery and mortars), reducing the amount of ammunition needed to achieve the effect.

- Combatting all types of UAVs is becoming a vital task for air defence units, but there is still no optimal, cost-effective solution. It is also relevant to be able to detect UAVs and provide advance early warning to your own units.

\section{Tanks}

According to official data as of 1 March 2014, the Armed Forces of Ukraine had $424 \operatorname{tanks}^{18}$ :

18 retrieved from Міністерство оборони України, http://www.mil.gov.ua/; Сколько танков в Вооруженных силах Украины? часть 1, LIVEJOURNAL, 29.07.2014, https:// altyn73.livejournal.com/599180.html [accessed: 20.08.2015]. 


\begin{tabular}{|l|l|l|}
\hline Unit & Sub-units & Number of tanks \\
\hline 1 Tank brigade & 3 battalions & 95 \\
\hline $\begin{array}{l}\text { 17 Tank brigade, } \\
24 ; 28 ; 30 ; 51 ; 92 ; 93 \text { mechanized infantry brigade }\end{array}$ & $\begin{array}{l}1 \text { tank battalion in the } \\
\text { structure }\end{array}$ & 243 \\
\hline 128 mechanized infantry brigade & 1 company & 10 \\
\hline 300 training centre & 4 companies & 41 \\
\hline Military schools & 3 companies & 30 \\
\hline Total & & 424 \\
\hline
\end{tabular}

a) The number of tanks in Ukrainian Army's units: company: 3 platoons + commander's tank - 10 tanks, battalion: 3 companies + commander's tank - 32 tanks, regiment: 4 companies + commander's tank - 41 tanks.

Table 4. Overview of units equipped with tanks

\begin{tabular}{|l|l|l|}
\hline Type of tank & Location of deployment & Number \\
\hline T84 „OPLOT” & $\begin{array}{l}1 \text { tank brigade } \\
300 \text { training centre }\end{array}$ & 10 \\
\hline T64 „BULAT” & $\begin{array}{l}1 \text { tank brigade } \\
300 \text { training centre } \\
\text { Military schools }\end{array}$ & 84 \\
\hline T64B and T64BV & In front-line units & approximately 320 \\
\hline T-55 and T-72 & & approximately 10 \\
\hline
\end{tabular}

\section{Table 5. Types of tanks deployed}

At the beginning of the armed operations, at least formally, only the Ukrainian side was exclusively equipped with tanks; however, tanks soon appeared on the separatist side as well. They came from museums, storage in Artemivsk and from the Russian Federation as security assistance. A curious case was to bring back into action a JS-3 tank which was located on a pedestal in Konstantynivka as a monument. Moreover, several T-34 tanks were also revived.

In the autumn of 2014, the latest T-72B3 Russian tanks appeared on the separatist side, they were fitted with sights, thermal imagers and improved shell loading systems for the new projectiles, which immediately revealed a weakness of the Ukrainian tanks which were not equipped with such updates.

With the war operations launched, the Ukrainian forces used tanks as the higher command's reserves, dispersing them in various units or positions, which consequently deprived the tanks of their basic force achievable in massive operations.

Open sources information, photographic evidence, shows the following tank losses by 30 September 2014: the Ukrainian side - 143 tanks, the separatists - 57 tanks. 
Due to the lack of tactical air forces over the battlefield, once again tanks proved their „ultima ratio" both in attack and in defence as well. They were a decisive factor in many clashes also because of the possibility to survive indirect artillery fire as its overall land forces light armour capability was a basic source of human losses.

The Ukrainian side concentrated on the reconstruction (as most of the tanks in their stocks were defective) and repair of the tanks they had at their disposal. Tanks produced for third countries were taken over from production plants and used in battle. The problem remained with the quality of repairs and time frames and delays were unacceptable.

There is no confirmed information concerning guided missiles fired from tank barrels during the fighting. It is highly possible that such an option was not applied because of the lack of missiles and also the burden of using them. It was noticed in the Georgian conflict in 2008 that tank crews avoided using this kind of weaponry because the tank must remain still during the whole missile flight and, in this way, it becomes an easy target itself.

The fundamental conclusion to the using of tanks is the necessity to equip them with thermal cameras, and the quality of ammunition is also of vital importance (or at least being equipped with ammunition as sometimes tanks entered the battle with only a few shells and not necessarily those which were needed in a given moment). Additional armour, including reactive plates, is a must, as is the repair/replacement on time of the reactive plate tiles lost as a result of hits. There is a picture showing the reactive armour explosion preventing the tank from being penetrated, but a second attempt to destroy the tank in that place would inevitably kill the tank.

\section{Field artillery, howitzers, rocket and missile artillery systems}

In contemporary conflicts, the lion's share of destroyed targets is allocated to air forces (approximately. 70\%), only the rest falls prey to artillery. In Ukraine, due to the absence of air forces' engagement ${ }^{19}$, the basic destructive force was artillery.

19 In the initial period of fighting, the Ukrainian side tried using air forces. However, it soon appeared that separatists had well organised air defence systems at their disposal. The 
During war operations, all artillery systems that both sides had at their disposal were used, including archaic ones, from $82 \mathrm{~mm}$ mortars to tactical missile systems.

\begin{tabular}{|c|c|c|c|}
\hline \multicolumn{4}{|l|}{ Barrel artillery } \\
\hline Type & $\begin{array}{l}\text { Calibre } \\
(\mathrm{mm})\end{array}$ & & Number \\
\hline 2S7 Pion & 203 & $\begin{array}{l}\text { museum piece, adopted for nuclear } \\
\text { weapons }\end{array}$ & 99 \\
\hline 2S19 Msta-S & 152 & & 40 \\
\hline 2 S6 Giatsint & 152 & & 24 \\
\hline 2S3 Akatsiya & 152 & & 270 \\
\hline 2S1 Gvozdika & 122 & & 300 \\
\hline 2S9 Nona $S$ & 120 & Self-propelled mortar & 50 \\
\hline $2 \mathrm{~A} 65$ Msta B & 152 & & 166 \\
\hline D20 & 152 & Construction from 1947 & 130 \\
\hline D30 & 122 & & 154 \\
\hline \multicolumn{4}{|l|}{ Mortars } \\
\hline 2S4 Tyulpan & 240 & Adopted for nuclear weapons & no data \\
\hline 2B16 Nona-K & 120 & & 2 \\
\hline 2S12 Sani & 120 & & 40 \\
\hline 120-PM-38 & 120 & & 40 \\
\hline 2B14 & 82 & & no data \\
\hline 2B9 Vasilek & 82 & Automatic, using 4-round clips & no data \\
\hline \multicolumn{4}{|c|}{ Tactical missile systems and rocket artillery systems } \\
\hline 9K79-1 Tochka U & 650 & Tactical ballistic missile system & 90 \\
\hline 9K58 Smerch & 300 & & 80 \\
\hline 9K57 Uragan & 220 & & 70 \\
\hline BM21 Grad & 122 & & 200 \\
\hline 9K54 Grad B & 122 & & no data \\
\hline
\end{tabular}

Table 6. Artillery systems deployed in Ukraine before the conflict (beginning of 2014)

Ukrainian combat losses from April to the end of August 2014 amounted to 19 aircraft, 18 of which were lost during missions. Despite this, 17 helicopters were damaged and needed to land, 10 retreated after being damaged at airports. High losses and lack of effectiveness in operation eliminated Ukrainian air forces from the battlefield. M. Gawęda, Ukrainskie lotnictwo w wojnie o Donbas, Magnum-X, Lotnictwo 11/2014, http://www.magnum-x.pl/ artykul/ukraiskie-lotnictwo-w-wojnie-o-donbas [accessed: 30.05.2015]. 
The number of artillery systems kept in Ukrainian storage before the outbreak of the war is not known. However, their deployment allowed not only the reconstructing but even the increasing of its artillery capabilities for the army after the defeat in 2014.

During the operations, artillery used concentrated fire, especially against fixed objects or facilities, such as fortified posts. Usually, at a particular time, there was a concentration of both howitzers and rocket artillery fire, shooting with a maximum of speed several salvos and retreat. The landscape of the target area resembled the surface of the moon afterwards.

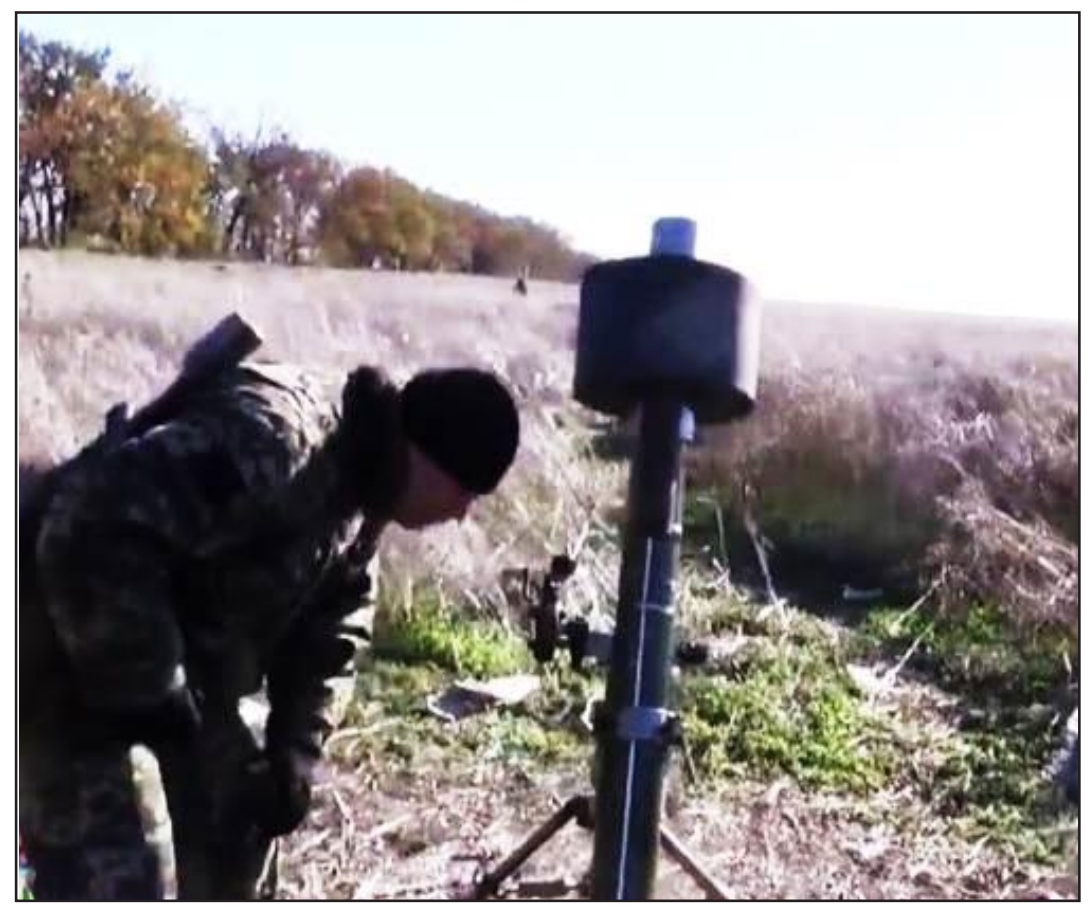

https://www.youtube.com/watch?v=YhnnbORLWvg.

Testing the fire suppressor on 82mm mortar, Donetsk, autumn 2014

Separatists occasionally used anti-tank homing artillery shells. There are pictures showing Ukrainian tanks hit from above which excludes battlefield artillery. This is a method to destroy tanks for the future, as new armour technique projects lead to a situation when it will not be possible to destroy a tank horizontally with a single hit, regardless of the effector. 
Currently, the issue of artillery systems' production in Ukraine is being decided. One of the biggest challenges to address is the cannon barrels production as their production capabilities have been lost. A small-scale series production of $120 \mathrm{~mm}$ mortar barrels has been launched ${ }^{20}$.

The trend for installing flash suppressors has affected artillery as well. Separatists from Donetsk constructed and tested a flash suppressor for an $82 \mathrm{~mm}$ mortar. However, neither the final results of that test nor further development of the project are known (in fact even whether the construction even survived the shot). There are also photos of a flash suppressor mounted on an AGS-17 automatic grenade launcher. The mania for mounting flash suppressors on all barrels is connected with the desire to avoid retaliation fire; the logic in the case of mortars and automatic grenade launchers does not appear sound, as the Ukrainian side received acoustic artillery locating radars from the Americans.

In order to provide a sufficient number of rocket artillery systems, there were attempts to mount them on MTLB chassis, whereas now the project of upgrading BM12 rocket launcher is continuing ${ }^{21}$.

Video footage shows that separatists widely used the Grad P system (a light portable rocket system developed in the 1960s to help the North Vietnamese forces). According to Ukrainian sources, its production was even launched in Luhansk.

Another problem for the Ukrainian Army was the lack of ammunition for heavy artillery rocket systems, such as the 9K58 Smerch and 9K57 Uragan.

In order to increase the artillery systems' efficiency, steps were taken by the Ukrainians to create a computerised fire management system. This project was called the GIS-ARTA and is run by volunteers and was started due to a bottomup initiative. The system ensures target systematisation, developing parameters of shots and communication with neighbouring units. Fire tests were conducted

20 Навооружение ВСУвскоредолжен поступить новый 120 ммминометукраинского производства Молот, Novoe Vremya, 6.10.2015, http://nv.ua/ukraine/events/navooruzhenie-vsu-vskore-dolzhen-postupit-novyj-120-mm-minomet-ukrainskogoproizvodstva-molot-72626.html [accessed: 15.12.2015].

21 РСЗО „Град” нового поколения в украинской армии будет на КрАЗах, Autoconsulting, 3.12.2015, http://www.autoconsulting.com.ua/article.php?sid=34883 [accessed: 30.12.2015]. 
in the brigade composition, and the system covered the whole frontline in 2016. According to the system developers, the system is fully mature and can be compared to the German Adler or French Finder systems. It was installed in 150 units and its marketing promotion is now being carried out ${ }^{22}$.

The separatist side also attempted to introduce computerised systems to support artillery fire.

Particular attention needs to be paid to automating and streamlining procedures, as well as reducing the cost of time needed to detect, identify, and decide on a target. This is not possible without the introduction of a wide range of automated systems.

Anti-tank armament

After the outbreak of war in 2014, anti-tank armaments were available only for the separatists but after Russia's intervention and deploying heavy armour equipment to Donbas, it also became accessible to the Ukrainian side.

The lack of combat air force and terrain conditions led to an unexpected renaissance of barrel anti-tank artillery.

\begin{tabular}{|l|l|}
\hline Model & Calibre, $\mathbf{m m}$. \\
\hline T12/MT12 (part with 1A31 radiolocation sight) & 100 \\
\hline D48 & 85 \\
\hline D44 & 85 \\
\hline
\end{tabular}

Table 7. Barrel anti-tank artillery used by Ukraine in the conflict

The T12/MT12 „Rapira” anti-tank gun also proved useful to carry out indirect fire, particularly used as long as the number of operational howitzers decreased. The great energy of the projectile and lower requirements concerning the crew's skills are also worth mentioning.

22 The authors were acquainted with two other systems, according to their constructors not worse than GIS-ARTA at Arms and Security exhibition (Kiev 11-14.10.2016). 
The first confirmed anti-tank guided missile systems were noted during the siege of Luhansk in 2014. Russian-backed separatists used 9K111 Fagot (AT-4 Spigot), 9K115 Metis (AT-7 Saxhorn) 23. Later, 9M113 Konkurs (AT -5 Spandel), and newer 9K135 Cornet (AT-14 Spriggan) appeared. The Ukrainian forces used 9K114 Shturm-S (AT-6 Spiral). According to unconfirmed information, missiles used by the Ukrainians often missed their targets, which was attributed to the Russian electronic warfare systems. The use of anti-tank missiles was not only limited to destroying tanks but they were often applied as infantry support.

The Ukrainian defence industry developed and offered its armed forces several anti-tank guided missile systems such as PK-3 Corsar ${ }^{24}$, Stugna P25, Barrier ${ }^{26}$, Skif ${ }^{27}$. However, their production did not proceed, despite the fact that their declared characteristics are very good.

\section{Mines and improvised explosive devices (IEDs)}

Contrary to the Russian Federation, Ukraine signed the Ottawa Mine Ban Treaty (The Convention on the Prohibition of the Use, Stockpiling, Production and Transfer of Anti-Personnel Mines and on their Destruction). According to the Ukrainian government's information, 1,219,008 mines had been destroyed, whereas 5,584,373 mines had been stored before the conflict broke out. They included $^{28}$ :

23 After a certain time it was revealed that AT-7 after a shot stopped reacting to operator's commands. The reason could be either its improper storage or lack of operator's skills.

24. Available since 2013. A characteristic feature - laser-guided missile, the operator cannot move during its flight. There are no cases of combat use.

25 In service since 2011. One video shows its use in battles at Donetsk airport. A special feature - semi-automatic by laser beam guided system, no thermos-vision channel.

26 In service since 2011, it is a modification of Mi-24. It is mounted on remotely controlled turrets in BTR-3E, BTR-4, BTR-7..

27 Ukrainian - Byelorussian construction, actively promoted on foreign markets.

28 Speech of the representative of Ukraine 2015 June $15 \mathrm{~d}$ at the Convention on the Prohibition of the Use, Stockpiling, Production and Transfer of Anti-Personnel Mines and on Their Destruction http://www.apminebanconvention.org/fileadmin/APMBC/IWP/IMJune15/2e_COOPERATIVE_COMPLIANCE_COMMITTEE_Ukraine.pdf. 


\begin{tabular}{|l|l|}
\hline Name of mine & Number \\
\hline PFM (ПФМ) & $5,434,672$ \\
\hline POM-2 (ПОМ-2) & 149,096 \\
\hline OZM-4 (O3M-4) & 605 \\
\hline
\end{tabular}

Table 8. Types of mines

According to the information released by the Ukrainian side, since July $2014^{29}$ separatist forces started to use mine barrages where standard Soviet mines were planted. Moreover, improvised explosive devices started to be used quite widely ${ }^{30}$. The first report of such a weapon appearing was issued in May $2014^{31}$.

Separatists planted the following anti-personnel land mines: $\Pi \mathrm{MH}, \Pi М Н-4$, ПОМ-2P, О3М-72, MON 50, MON-50/90/100, booby-traps. The НВУ-П mine $^{32}$ is particularly interesting as it is a smart mine selecting targets using a microprocessor, and is fitted with a seismic fuse.

Both sides used the same TM-62m and TM -72 anti-tank mines.

The basic problem connected with using mines is the chaos which ensues while planting minefields, as required procedures were not always applied. This problem appeared especially while planting tripwires in order to protect their own defensive positions. The mines were planted traditionally to protect one's own territory and unconventionally by planting minefields on enemy territory after having infiltrated the enemies terrain ${ }^{33}$.

29 Terrorists are conducting mine warfare contrary to the Ottawa Convention, Censor.NET, 7.07.2014, https://en.censor.net.ua/photo_news/292965/terrorists_are_conducting_mine_ warfare_contrary_to_the_ottawa_convention_ministry_of_defense_photos [accessed: 28.08.2015].

30 Оригинальные мины ополчения из подручных вещей новости Украины АТО $\Lambda H P$ AHP, 1208 2014, https://www.youtube.com/watch?v=3EhKZYlaUbo [accessed: 25.08.2015].

31 СВУ на Украине, LiveJournal, 31.05.2014, http://twower.livejournal.com/1313701. html [ accessed: 28.08.2015].

32 NBU-P Detonating Device, zIFBoards, 6.03.2009, http://z4.invisionfree.com/ NSDraftroom/ar/t5649.htm [accessed: 30.07. 2015].

33 Украина.БТР наехал на мину.Колонна сил АТО. Террористы разбрасывают мины по всему Аонбассу, YouTube, 4.08.2014, https://www.youtube.com/watch?v=S2rJk13-K94 [accessed: 15.08. 2015]. 


\section{Electronic warfare}

There is not enough reliable information relating to the electronic warfare assets used by both sides. There are photos and videos in which elements of particular systems are visible, combatants' reports, observers' accounts; however, not all of them are credible ${ }^{34}$.

Electronic warfare assets were used at the beginning of the conflict in Crimea. In the course of the operation to eliminate Ukrainian forces, communication channels were blocked first of all, some of them even taken over. The Russian side does not provide very reliable information stating that in that time, two American UAVs were seized (there are pictures showing the Avtobasa system 2 capable of doing this, at the airport in Simferopol).

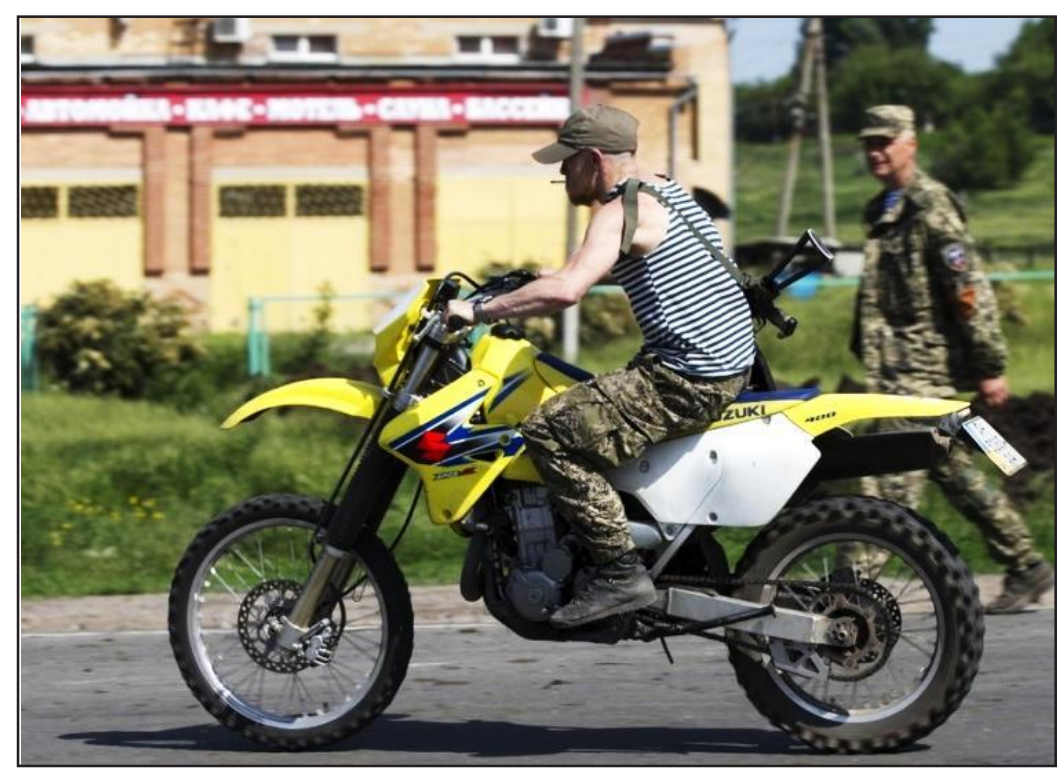

AP Photo/Alexander Zemlianichenko; http://www.whq-forum.de/invisionboard/index.php?sho wtopic $=29782 \& s t=2793$.

Separatist communication method (works in electronic warfare conditions too...). Outside Slovyansk, eastern Ukraine. 2014-05-18

34 Missing a target by guided anti-tank missiles might result from poor operator training but also there are statements that it might be due to electronic warfare assets used by separatists. 
During battles in Donetsk, a new stage of electronic warfare began, particularly from the Russian Federation side. Civilian GSM networks were taken over. Consequently, acquiring information regarding location of particular mobile phones became possible. Having known Ukrainian commanders' mobile phone numbers, separatist rocket artillery used that information to shell the place of emission. Eventually, the use of mobile phones by soldiers was controlled and burner phones (burners) were eventually widely used ${ }^{35}$.

The following systems have been identified:

\begin{tabular}{|l|l|l|}
\hline System & Country & Remarks \\
\hline AN/TPQ-36 & USA /Ukraine & Weapon tracking radar \\
\hline AN/TPQ-48 & USA /Ukraine & Weapon tracking radar \\
\hline ARK-1 & Ukraine & Weapon tracking radar \\
\hline SNAR-10 & RF/Ukraine & Weapon tracking radar \\
\hline 9S80 „Dog Ear” & Ukraine & Radar plot (ARPA) \\
\hline Torn $^{\text {a) }}$ & Ukraine & Electronic warfare system \\
\hline Mandat (Borisoglebsk 1) $)^{\text {b) }}$ & RF & Electronic warfare system \\
\hline Murmansk & RF & Located in Crimea. Electronic warfare system \\
\hline
\end{tabular}

а) Возле ААП выявлен новейиий комплекс радиоразведки ВС РФ «Торн», InformNapalm. org, 1.09.2015, https://informnapalm.org/12200-kompleks-radyorazvedky-torn-dap/ [accessed: 15.12.2015].

b) Новейшие российские комплексы РЭБ «Борисоглебск-2» забиксировань у границы и в зоне ATO, InformNapalm.org, 28.07.2015, https://informnapalm.org/11087-rebborisoglebsk-2/ [accessed: 15.12.2015].

Table 9. Electronic warfare systems

There is unconfirmed but rather unreliable information concerning the use of a broadband electronic warfare system Krasukha-2 (and even Krasukha-4) in Donbas, which can intercept and jam signals emitted by airborne systems - reconnaissance satellites, AWACS and UAVs, as well as ground stations. The Ukrainian side complained many times about interference to communication systems' (which is not difficult due to the poor quality of Ukrainian equipment) and UAVs communication failures. On the other hand, due to the scope of the Krasukha operation, the system could have been located on Russian territory.

35 Mi-24 helicopter pilots, who were shot down on 4.06.2014 had such mobiles, which worked out because probable radio emission could have been promptly located by separatists. The pilots manged to return. 


\section{Conclusions}

The 2014-2015 conflict in Ukraine allowed the authors to review all kinds of Soviet and Russian land forces' armaments in a real combat situation as well as the tactics for using them, which allows us to draw the following conclusions:

- After the first period of operations, the basic problem became logistics support; after mobilisation; the provisioning of equipment and weapons were the biggest challenges.

- The core of the operation - a tank with reactive armour is an undisputed necessity and it is vital to restore its combat capability as soon as possible after the battle.

- Artillery was the basic destructive force. Quick heavy artillery fire, often with rocket artillery, cluster munitions and guided missiles was also used. There is clearly a visible reduction of the decision making time and implementing of support systems.

- Heavy machine guns and grenade launchers penetrating body armour and other obstacles were widely used. The role of snipers and sharp-shooters, including those with anti-materiel rifles, increased.

- A dramatic growth in the demand for night-vision and thermo-vision devices for individual soldiers as well as platform type equipment e.g. tanks, wheeled armoured vehicles, and combat infantry vehicles.

- Tremendous growth in the use of UAVs, combatting them is a great problem.

- Light armoured vehicles became the main source of human losses. Logistics transportation must be armoured as well.

- Electronic warfare elements became considerably important. A crucial task is to provide one's own sub-units with secure encrypted communication. Individual tactical communications assets become necessary.

- Small coordinated groups operated using all methods of fighting (e.g. long raids). Additionally, cooperation with the media was used for the purpose of furthering the propaganda campaign.

This article, in principle, does not exhaust the topic as it was exclusively based on video and photographic materials available when the conflict developed and from scarce publications, without analysing any general comprehensive works (simply non-existent). On the other hand, visual materials are much more reliable than 
any reports, especially written after some time has passed. The confrontation of both sources should present a broad image of the subject, which is extremely important in light of the development of the current geo-political situation in the region.

\section{Bibliography}

America is supplying lethal weapons to Ukraine through Bulgaria - Russian source, STANDART News, September 2015, http://www.standartnews.com/english/read/ america_is_supplying_leathal_weapons_to_ukraine_through_bulgaria_russian_ source-9702.html

Domasheva Y. Azeev E. Sidorenko L., Под Краматорском погибли шесть украинских военных (Six Ukrainian soldiers died at Kramatorsk), Komsomolskaya Pravda v Ukraine, 13.05.2014, http://kp.ua/politics/452433-pod-kramatorskom-pohybly-shestukraynskykh-voennykh

Gawęda M., Ukraińskie lotnictwo w wojnie o Donbas, Magnum-X, Lotnictwo 11/2014, http://www.magnum-x.pl/artykul/ukraiskie-lotnictwo-w-wojnie-o-donbas

Gerasimov S., Видео Эксклюзив МОТОРОАА проверил боевые позиции в Семеновке, 05.06.2014, https://www.youtube.com/watch?v=LalrD23V61s

Игорь (Бес) Безлер: начнем наступление, когда противник выдохнется, RIA Novosti, 16.07.2014, http://ria.ru/interview/20140716/1016094469.html\#ixzz4C79pAgHl

Kasyanov Y., Как был уничтожен 1-й блокпост, (How the first post was destroyed), Cenzor.net, 28.06.2014, http://censor.net.ua/resonance/291942/kak_byl_unichtojen_ 1yi_blokpost

Колонна украинских военныхх попала в засадув Харьковской области, Focus, 10.06.14, http://focus.ua/country/308099/

Mahmudov F., Commander of "Ghost" brigade (LPR Army) Aleksey Mozgovoy was assassinated, APA, 23.05.2015, http://en.apa.az/world-news/cis-countries-news/ commander-of-ghost-brigade-lpr-army-aleksey-mozgovoy-was-assassinated.html

Moshkin M., Атамана Батю взорвали в автомобиле после свадьбы, Delovaya Gazeta Vzglyad, 12.12.2015, http://www.vz.ru/incidents/2015/12/12/783478.html

NaberejnovG.,В Ауганскеубитобвиняемыйвпыткахкомандирополченцев «Бэтмен», RBK, 2.01.2015, http://www.rbc.ru/politics/02/01/2015/54a6ad809a794737b58c4ea3

На вооружение ВСУ вскоре должен поступить новый 120 мм миномет украинского производства Молот, Novoe Vremya, 6.10.2015, http://nv.ua/ukraine/events/navooruzhenie-vsu-vskore-dolzhen-postupit-novyj-120-mm-minomet-ukrainskogoproizvodstva-molot-72626.html 
NBU-PDetonatingDevice, zIFBoards, 6.03.2009, http://z4.invisionfree.com/NSDraftroom/ ar/t5649.htm

Новейшие российские комплексы РЭБ «Борисоглебск-2» зафиксированы у границы и в зоне ATO, InformNapalm.org, 28.07.2015, https://informnapalm.org/11087-rebborisoglebsk-2/

Оригинальные мины ополчения из подручных вещей новости Украины АТО АНР АHP, 12.08.2014, https://www.youtube.com/watch?v=3EhKZYlaUbo

РСЗО „Град” нового поколения в украинской армии будет на КрАЗах, 3.12.2015, http://www.autoconsulting.com.ua/article.php?sid=34883

СВУ на Украине, LiveJournal, 31.05.2014, http://twower.livejournal.com/1313701.html

Sharkovsky A., Война на юго-востоке Украинь меняется качественно, Nezavisimoe Voennoe Obozrenie, 22.05.2015, http://nvo.ng.ru/realty/2015-05-22/1_ukraina.html

Сколько танков в Вооруженньх силах Украинь? часть 1, LIVEJOURNAL, 29.07.2014, 2015, https://altyn73.livejournal.com/599180.html

Terrorists are conducting mine warfare contrary to the Ottawa Convention, Censor.NET, 07.07.2014,https://en.censor.net.ua/photo_news/292965/terrorists_are_conducting mine_warfare_contrary_to_the_ottawa_convention_ministry_of_defense_photos

Террористы расстреляли украинских солдат под Волновахой, Sait Mariupola 0629. cm.ua, 22.05.2014, http://www.0629.com.ua/article/539570, https://www.youtube. $\mathrm{com} /$ watch?v=9yEhQ21BrCA

Украина. БТР наехал на мину. Колонна сил АТО. Террористы разбрасывают мины по всему Аонбассу, YouTube, 4.08.2014, https://www.youtube.com/watch?v=S2rJk13K94

Від вибуху на Аонеччині постраждало двоє військових, один з них помер, Ukrainska Pravda, 28.04.2014, http://www.pravda.com.ua/news/2014/04/28/7023883/

Возле ААП выявлен новейший комплекс радиоразведки ВС РФ «Торн», InformNapalm. org, 1.09.2015, https://informnapalm.org/12200-kompleks-radyorazvedky-torn-dap/ 